\title{
ЦИТ: ua117-059
}

DOI: $10.21893 / 2415-7538.2016-05-1-059$

УДК 338

Зинькович Е.С.

ЭКОЛОГИЧНОСТЬ ПРЕДПРИЯТИЙ ПИЩЕВОЙ ПРОМЫШЛЕННОСТИ КАК ФАКТОР УСПЕШНОГО РАЗВИТИЯ И POCTA

Московский государственный университет пищевых производств, Москва, Волоколамское шоссе, 15, 125080

Zinkovich E.S.

\section{SUSTAINABILITY OF THE FOOD INDUSTRY AS FACTOR OF SUCCESSFUL DEVELOPMENT AND GROWTH}

Moscow State University of Food Production

Moscow, Volokolamskoe avenue, 15, 125080

Аннотаџия: В данной работе рассматривается сущуность «зеленой» экономики и основные принциипь экологизации производства. Также описаньл возможности и выгоды для предприятий, которые применяют данные принцииьы и стандартыл.

Ключевые слова: «зеленая》 экономика, «зеленая» промьиленность, экологизачия производства, декаплинг.

Abstract. In this paper we describe the essence of "green" economy and the basic principles of ecologization of production. Also, describes the capabilities and benefits for enterprises that apply the principles and standards.

Key words: green economy, green industry, ecologization of production, the decoupling.

\section{Вступление}

В последнее время все более популярным трендом у предприятий является внедрение принципы «зеленой» экономики и экологичности своих производств, что позволяет игрокам в отрасли справиться с существующими социальными проблемами, обеспечить себе экологически - ориентированный рост и, наконец, повысить уровень своей конкурентоспособности.

В связи с этим и возникает необходимость применения сбалансированных способов производства и эффективного использования ресурсов.

\section{Основной текст}

Благодаря необходимости внедрения принципов экологизации промышленности и производств, в 2011 году Программа ООН по защите окружающей среды (ЮНЕП) ввела определение «зеленой» экономики как «программы, предназначенной для улучшения благосостояния населения и достижения социального равенства при одновременном сокращении рисков для окружающей среды и экологического дефицита».

Согласно определению UNIDO, «зеленая» промышленность является важным инструментом достижения устойчивого промышленного развития, которое, в свою очередь, включает двухкомпонентную стратегию развития благодаря экологизации существующих отраслей промышленности, и создание 
новых «зеленых предприятий».

Благодаря экологичности производств, ОСЭР ввело термин «декаплинг» и определило его как «устранение связи между вредом для экологии и экономической выгодой». [1] Данный термин относится и к производству продукции пищевых производств, включая все стадии производственной цепочки.

Рассмотрим современное состояние экологизации промышленности на примере отрасли пищевых производств. Прежде всего отметим, что принципы экологичности производств включены в отчеты компаний по корпоративной социальной ответственности. Включенные в данный отчет инициативы направлены на управление природопользованием и цепочкой создания стоимости, управление рисками и повышения безопасности работников, производств, улучшения качества продукции.

Яркими примерами в рассмотрении данного вопроса на отечественном рынке являются иностранные предприятия.

Например, французская компания Danone в своей деятельности руководствуется следующим принципом: «Нести здоровье людям без ущерба для здоровья нашей планеты». Экологизация производства в этой компании входит в число приоритетных задач. В начале 2017 году Danone и швейцарская компания Nestle объединили свои усилия в области производства безопасного пластика. Обе компании начали совместное финансирование калифорнийской биотехнологической компании, в которой и происходит разработка и тестирование нового пластика для бутылок.

Американская компания Mars в 2016 году открыла 10-е предприятие на территории России, которое изначально строилось с учетом требований золотого стандарта международной экологической сертификации и будет самым зеленым производством компании в нашей стране.

Политика компании Fazer в области качества, безопасности продукции, экологии и охраны труда (QEHS) определяет приверженность руководства принципам качества и безопасности пищевых продуктов, а также экологической безопасности. В компании проводятся внутренние аудиты и проверки для установления соответствия в области экологии, качества и безопасности труда.

Компания Coca-Cola в России в 2016 году запустила федеральную образовательно - просветительскую Программу «Разделяй с нами!». Данный проект направлен, прежде всего, на обучение населения правильно собирать отходы. Также компания уже несколько лет инвестирует в производство экологически чистой упаковки для линейки своей продукции.

\section{Заключение}

Все больше предприятий, являясь загрязнителями окружающей среды, внедряют различные мероприятия в области природоохранной деятельности и берут на себя повышенную экологическую ответственность.

Многие предприятия пищевых производств разработали принципы поведения и ведения своего бизнеса согласно принципам «зеленой» экономики и экологичности производств. Также предприятия поддерживают открытый и 
честный обмен информацией как внутри компании, так и за ее пределами, становясь «прозрачными» для инвесторов, партнеров, государства и потребителей.

Внедрение предприятиями принципов «зеленой» экономики способствует получению не только экологических выгод, которые выражены в виде снижения объемов отходов производства и более эффективного использования ресурсов, то также социальных и экономических, таких как: интенсивный рост производства, стабильность предприятия, повышение его доходности и повышение степени влияния на рынке.

Список литературы:

1. www. Green industryplatform.org- Инициатива ЮНИДО в области «зеленой» промышленности по устойчивому промышленному развитию

2. www.danone.ru - Официальный сайт компании Danone в России

3. www.fazer.ru - Официальный сайт компании/Политика компании

Статья отправлена: 01.04.2017 (C) Зинькович Е.C.

\section{ЦИТ: иа117-090}

DOI: 10.21893/2415-7538.2016-05-1-090

УДК 331.5.024.5

Пионтовский И.Н.

РОЗВИТОК СИСТЕМИ ПЕНСІЙНОГО ЗАБЕЗПЕЧЕННЯ В РОСІЇ В ЦІЛЯХ ПІДВИЩЕННЯ ЯКОСТІ ЖИТТЯ ОСІБ СТАРШОГО ВІКУ

Российский государственный университет правосудия, Хабаровск, Восточное шоссе 49, 680018

Piontovskii I.N.

\section{THE DEVELOPMENT OF THE PENSION SYSTEM IN RUSSIA IN ORDER TO IMPROVE THE QUALITY OF LIFE OF OLDER PERSONS}

Russian State University of Justice, Khabarovsk, Vostochnoe hw 49, 680018

Анотаиія. Розвиток пенсійної системи в Росії триває весь час активних економічних реформ, але до иього часу так $і$ не вдалося виробити ефективну модель пенсійного забезпечення населення при якій якість життя осіб старшого віку відповідало б середньоєвропейського рівня. У зв'язку з цим, проблеми якості життя осіб старших вікових груп і пенсійного забезпечення вимагають системного підходу для вироблення зважених рішень.

Ключові слова: пенсіонери, економічна активність, старший вік, трудовий потенціал, зайнятість, пенсійна система, якість життя

Abstract. The development of the pension system in Russia continues all the time of active economic reforms, but so far failed to develop an effective model of pension coverage of the population at which the quality of life of older persons would be consistent with the European average. In this regard, issues of quality of life of persons in older age groups and pension funding requires a systematic approach for 